\title{
Chapter 2 \\ Institutional and Technological Innovations in Polycentric Systems: Pathways for Escaping Marginality
}

\author{
Franz W. Gatzweiler
}

\begin{abstract}
There is increasing consensus that institutional innovations are just as important for development as technological innovations. Polycentric systems are social systems of many autonomous decision centers operating under an overarching set of rules. The rural poor hold positions in polycentric systems, which are marginalized as a result of poverty, exclusion and degraded environments. Horizontal and vertical position changes by means of technological and institutional innovations within polycentric systems create escape routes from marginality. Productivity growth in agriculture through technological innovations is one way to enhance the wellbeing of the rural poor. Sustainable productivity growth, however, also requires institutional innovations. This contribution shows pathways for escaping marginality by means of technological and institutional innovations in polycentric systems.
\end{abstract}

Keywords Institutional innovations - Technological innovations - Polycentric systems • Marginality • Poverty

\section{Innovation in Polycentric Systems}

The rural poor are in positions in which they have limited options for selecting, with more or less control, from a set of alternative actions in light of available information about the general structure and outcomes that may be affected by benefits and costs assigned to actions and outcomes. This general situation is what Elinor Ostrom has referred to as an 'action situation' (Ostrom 2005, p. 189), and it serves as a starting point for describing how the rural poor can escape marginality in polycentric systems.

Polycentricity is "a social system of many decision centers having limited and autonomous prerogatives and operating under an overarching set of rules." (Aligica 2014 , p. 37). Because polycentric systems “...take each other into account in

\footnotetext{
F.W. Gatzweiler $(\bowtie)$

Center for Development Research (ZEF), University of Bonn, Bonn, Germany

e-mail: gatzweiler@gmail.com

F.W. Gatzweiler, J. von Braun (eds.), Technological and Institutional Innovations for Marginalized Smallholders in Agricultural Development,
} DOI 10.1007/978-3-319-25718-1_2 
competitive relationships, enter into various contractual and cooperative undertakings or have recourse to central mechanisms to resolve conflicts..." they are not chaotic, but "function in a coherent manner", and therefore, Vincent Ostrom defines them as "systems" (Ostrom et al. 1961, p. 831). Ostrom (2005, p. 11) also refers to polycentricity as institutions being organized in multiple hierarchies of nested part-whole structures (see also Kiser and Ostrom 1982).

The concept of polycentricity has been used to refer to a particular type of multi-level organization (Aligica 2014; Aligica and Tarko 2012; Ostrom 1972, 1999a, b). Within polycentric order, rules govern action situations at multiple, nested hierarchical levels. Within the nested hierarchy of governance, at the operational level of decision-making, rules directly shape the outcomes of actions, for example, rules defining the amount and timing of fertilizer application on a field. Operational level rules are contained in and affected by the rules at a higher collective-choice level of decision-making.

Rules at the collective-choice level govern action situations, the outcomes of which are rules which define the operational-level rules. The collective-choice rules are affected by and contained in yet a higher level of decision-making, the constitutional choice level. Action situations in polycentric systems are therefore coupled. The ways in which systems of rules at each level match or complement rule systems at other levels has been addressed by the literature on institutional complementarity. Institutional complementarity (Aoki 2001; Gagliardi 2013; Amable 2000; Hall and Gingerich 2004) has also been referred to as fit, match and interplay of institutions at multiple scales complementing and reinforcing each other in order to improve the robustness or other performance criteria of social or ecological systems (Folke et al. 2007; Vatn 2012; Young 2002; Young et al. 2008). Such complementarities are specific to different types of technological innovations, types of actors and the strategies they follow, and the agro-ecological environments in which they operate (Gatzweiler 2014).

"Polycentric systems tend to enhance innovation, learning, adaptation, (...) and the achievement of more effective, equitable, and sustainable outcomes at multiple scales, ..."(Ostrom 2010, p. 552). Technical and institutional innovation occurs by movement and respective changes of interaction patterns within polycentric systems. Interaction patterns are defined by sets of rules, here referred to as institutions. Among others, institutions define what actors do, how they perform actions and in which positions. Institutions thereby define the actors' action possibilities in action situations - the actors' functioning. Functioning is what people are actually able to be and do - the realized capabilities, people's wellbeing or quality of life (Nussbaum and Sen 1993).

\section{Marginality in Polycentric Systems}

Marginality is an involuntary position of an individual or group at the margins of social, political, economic, ecological, and biophysical systems, that prevents them from access to resources, assets, and services, restraining freedom of choice, preventing the development of capabilities, and causing extreme poverty (von Braun and Gatzweiler 2014). The marginality framework has been developed 
to explore the social, economic, and ecological spaces in which poor smallholders can advance and tap unused capabilities and agro-ecological potentials.

Being marginalized means having a marginal position in polycentric systems. From an institutional perspective, being marginalized means being excluded from institutional frameworks which enable innovation of technological or institutional infrastructures. With reference to the picture of a bicycle chain, being marginalized means being constrained in "changing gears" and creating value at higher levels of polycentric order. Institutions of marginality cannot always be directly identified by specific attributes or forms of rule configurations in which they appear; rather, they can be detected indirectly ex-post by (1) the ways in which decisions are made, (2) the types of behavior and actions they enable or inhibit, and (3) the effects they have on society and the environment.

Those institutions which define the everyday lives of the marginalized do not enable them to improve their wellbeing vertically by creating value in systems at a higher polycentric order. ${ }^{1}$ Institutions of marginality consist of strong horizontal valuecreating institutions, e.g., strong bonding social capital institutions, like traditions, habits or life-long contracts. Survival networks and social networks protect the marginalized from life-endangering extremes, but also prevent them from having access to resources, rights and services outside their immediate social and physical environment.

Being marginalized means being excluded, especially from vertical value creation, and having to carry the costs which are externalized to secure private benefits of other, less marginalized actors. Further, geographical remoteness and being socially and culturally confined prevents structural coupling with higher level systems of governance in the polycentric order, such as collective-choice or constitutional level decision-making, for example, by claiming citizen rights, or by an attempt to act outside the boundaries of tradition. Being trapped in marginality is determined by situations in which actors are less well connected to higher orders of decision-making, have relatively low potential and low levels of resilience (Carpenter and Brock 2008). Although change is needed for improving livelihoods, it is risky. ${ }^{2}$ Therefore innovation often occurs among marginalized groups when potential and connectedness may be low but resilience is sufficiently high to absorb risks of failure.

\footnotetext{
${ }^{1}$ Operational, collective-choice and constitutional levels of decision making are levels of increasing polycentric order.

${ }^{2}$ To explain how institutions of marginality work, scholars have attempted to set up dichotomies of different types of institutions. North et al. $(2007,2009)$ explains how limited access orders work in contrast to open access orders. Acemoglu and Robinson $(2012,2008)$ identify extractive versus inclusive institutions in explaining why some nations prosper while others fail. Hagedorn (2008) refers to segregative in contrast to integrative institutions for explaining sustainable resource use in agriculture. Despite the different use of terms, all those theories contribute to explaining how institutions of marginality work: they limit access and property rights, create poverty and inequality, limit control of a community's rights to change it's own institutions, free the economic and political elites from accountability, and limit access to resources, rights, freedoms and opportunities. And, as Acemoglu and Robinson $(2008,2012)$ argue, most of the time, they are intentionally designed to extract resources and limit rights of a majority in favor of those of a political and economic elite.
} 


\section{Pathways Out of Marginality: Institutional and Technological Innovations}

Escaping marginality requires innovation in institutional and technological infrastructures. Technological innovations in agriculture refer to products or machines which are new in the production process, whereas institutional innovations are changes in sets of rules which define peoples' positions and actions in action situations.

Institutions are the sets of rules which emerge from the attempt to structure social interactions. Social interactions, in turn, are shaped by institutions. Within institutional structures, behaviors in action situations ${ }^{3}$ are motivated and enabled by reducing the costs involved in agreeing on why, when, and which actions are carried out, and by whom. The costs of agreeing on sets of rules can be substantial, and because of the sunk cost effect, they can actually be a reason for avoiding behavioral changes (Ostrom 2005, p. 58; Janssen et al. 2003; Janssen and Scheffer 2004). High investments for establishing political, social or economic arrangements which are cemented in institutional arrangements result in a resistance against reform, especially in periods of uncertainty and ecological vulnerability (Pakandam 2009).

Institutions enable and constrain actions within action situations. The boundaries of the action situation itself are defined by institutions, as well as membership, authority, and a variety of other rules which specify the scope of outcomes, the information available, or how costs and benefits are allocated (Ostrom 2005). Desired behavior is motivated by institutions, while undesired behavior is sanctioned. While some institutions have emerged spontaneously, without purposeful design, and have eventually become habits or traditions, others are the result of purposeful design. Either they are determined and imposed or they are the result of continuous deliberations and "struggles" to find and improve sets of rules which serve the purpose of the actors within or in charge of an action arena. Variations and combinations of both top-down and bottom up processes of institutional evolution are common (van den Bergh and Stagl 2003; Arnold 1980; Richerson and Boyd 2001; Farrel and Shalizi undated).

As technology always comes with rules on how to use the technology, who is to use it, and who has the rights to the outcomes from its use, institutional fit or complementarity is relevant for the adoption of technological innovations. Technological innovations can change action situations by changing roles and rights of actors related to the use of technology. Local technological innovations can

1. evolve from specific local institutional contexts (Fig. 2.1a), or

2. be developed elsewhere and introduced into specific local institutional contexts (Fig. 2.1b).

\footnotetext{
${ }^{3}$ An action situation involves "participants in positions who must decide among diverse actions in light of the information about how actions are linked to potential outcomes and the costs and benefits assigned to actions and outcomes" (Ostrom et al. 1994, p. 29).
} 

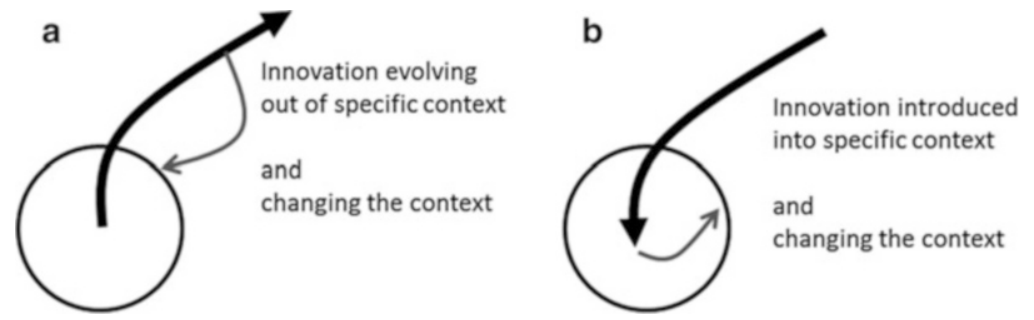

Fig. 2.1 Institutional or technological innovations evolving from (a) or introduced into (b) local contexts

When local technological innovations evolve from specific constraining contexts, they primarily intend to reduce workload or improve the working and living conditions of the marginalized. Grassroot innovators (Gupta et al. 2003) can improve their immediate working and living conditions despite being economically poor. This is not only because they possess intellectual capabilities and can be ingenious, but also because of their desire and motivation to lift the constraints of their work and living conditions.

The creativity of innovators is triggered by the adverse and constrained living and working conditions in which they are working. Although creativity usually declines under pressure (Amabile et al. 2002; Gunkel 2010), marginalized innovators attempt to improve their work and living conditions through innovations which make work processes easier, less dangerous and open opportunities. This seemingly adverse context for creativity results from tensions, conflicts and dilemmas which need to be resolved (Lewis et al. 2002; King et al. 1991) by means of creating a technological or institutional solution for an existing interaction pattern (status quo) which is perceived as being too costly or burdensome. The attempt to improve contextual fit or match (Bledow 2009; Young 2002) brings forth innovation. The enabling and inhibiting characteristics of institutions are also a potential source of conflict when actors are no longer willing to carry the costs of being constrained (see following chapter).

Alternatively, innovations which have been developed outside local contexts, once adopted, can change the specific local context with regards to who uses the technology, how it is made use of, and how costs and benefits from the use of it are allocated. In this case, the motivation to develop an innovation which mainly serves the interests of local communities is not always straightforward, as the innovator and the user are two different actors with different attributes and interests. Although innovators outside the local context can be motivated by noble goals (e.g., to help the poor increase yields by improved seeds), the incentive to implement a technology which has been costly to develop is high, and the hidden costs, like ecological externalities or additional costs required to accompany the innovation (e.g. fertilizers, pesticides, in the case of high yielding varieties), are less visible. From the perspective of the prospective users of the innovation, externally 
developed technologies are attractive because the costs for development are carried by an external innovator who can hide them in the per unit costs of the purchased technology over a long time period. Technologies externally developed for marginalized smallholders are not necessarily less sustainable than technologies developed from grassroot actors themselves, especially when the potential users of the technology have been part of the innovation process in innovation systems (Nyikahadzoi et al. 2012).

\section{Enabling and Inhibiting Functions of Institutions}

When do actors undertake efforts to change sets of rules which govern action situations? In other words, when do they undertake the effort to change institutions? Whereas institutions are the preconditions for continuity of interactions in changing and uncertain environments, institutions themselves frequently change and adapt to changing environments. Institutional innovation is also a result of the tension between the constraining and enabling functions of institutions.

When costs related to the constraining functions of institutions are perceived as too high, people undertake efforts to change them so that the benefits which can be captured by the enabling functions of institutions prevail. An incentive to change institutions can occur when the expected benefits from an old set of rules are less than the anticipated benefits from a new set of rules plus all the costs involved in the process of changing the rules - that is what Elinor Ostrom has referred to as the "rule change calculus" (2005, p. 245). When the old set of rules is perceived as being too costly, or when a set of institutions provide for too many constraints, actors may perceive the need for freedoms and institutional innovation. This need for change can only be perceived if an improvement of status quo is imaginable and when processes of structural coupling and cognition take place, as described above.

The variety of institutional arrangements in different action situations thereby “...provides the raw material for adaptation" (Axelrod and Cohen 1999, p. 32). Institutional arrangements define the decisions and actions people can take within action situations, as well as the relationships between actors interacting in those situations. They also define the linkages between action situations at various levels of the polycentric order. Accordingly, institutional innovations, here understood as rule changes or rule creations, can occur within or between coupled action situations, or they lead to the creation of rules (e.g., monitoring) which link action situations. Changing the relative frequency of types of rule configurations leads to institutional innovation.

Variety in rule configurations can be a source for innovation and wealth creation, however, "... beyond some level, variety ... can also be a source of debilitating inconsistency and conflict" (Axelrod and Cohen 1999, p. 122). This is the case when rule configurations in interaction domains provide space for too much individual wealth generation without contributing to collective (societal) wealth 
generation and without constraints from higher level institutions. The "tragedy of the commons" is a popular example (Hardin 1968).

Per definition, institutions have enabling and inhibiting functions. They enable interactions and functions within the subsystems they regulate, and thereby are an incentive for favorable behavior. They inhibit and create disincentives for unfavorable behavior. The rules created within a system or an organization can be perceived as enabling or constraining - depending on the cognition and aspirations of individuals within the organization. A constant adjustment process between internal and external organizational structures takes place, comparing status quo with how a system should or could be organized. This adjustment process has been referred to as structural coupling, or cognitivism (Rizzello 1999, p. 79) - a process that is structure-determined and structure-determining and that leads to structural congruence between two or more systems (Gatzweiler and Hagedorn 2013). This process of matching internal representations with external (changing) environments (Wexler 2008, p. 15), or structural coupling, is important for adaptation and survival in social and ecological systems.

Hagedorn (2008, p. 12) explains that institutions ' . . . are always (more or less) integrative and segregative at the same time. On the one hand, they are integrating the interests of those who want to be protected against adverse effects into the decision-making of other actors by exposing these to corresponding constraints. On the other hand, they secure reasonable room to manoeuvre for a decision-maker, even if this may require that not all adverse effects are kept away from other actors.' Institutions can thereby function as incentives or disincentives; they can reward or punish (Hodgson 2006, p. 2). They are never universal and always specific, and they are inclusive for some and exclude others.

How much freedom people have in the actions they can take and how constrained people are in the decisions they can make is defined by institutions. The adjustment process between enabling and constraining functions of institutions reoccurs in the discourse of freedom and organization. Vincent Ostrom $(1983$, p. 1) has defined freedom as ". . .the capacity to act on the basis of one's own considered judgment" and as "... the availability of adaptive potential." In that sense, development gains can be made when "...constraints (are built) into people's relationships..." and when "human beings (...) take advantage of each other's capabilities and pursue opportunities for joint advantage through teamwork."

In order to be able to tap those capabilities, it is necessary to "...establish a basis for creating stable expectations about their relationships with one another" (ibid., p. 3). Wealth creation under freedom can only be realized in the presence of organization. On the other side, organization requires rules, rulers and those being ruled. Grasping the benefits of ordered relationships is only possible if sanctions can credibly be imposed on defectors. If those who rule are excluded from the rules imposed on the ruled, organization can become a threat to freedom. "The prerogatives of rulership become a threat to freedom when organization provides unequal opportunities for some to exploit and oppress others" (ibid., p. 5). 


\section{Horizontal and Vertical Value Creating Institutions in Polycentric Order}

Institutional innovations which are enabling create value. Value creating institutions are part of polycentric order and therefore value can be created horizontally and vertically within polycentric systems. Enabling institutions can therefore be regarded as sets of rules which increase the set of opportunities for escaping marginality. They define the type of actions actors can take in action situations. Having access and being connected to those institutions enables actors to create value or, as in the case of public service provision, benefiting from value created by the community. Being fully included in the systems in which value is created means being able to make use of low institutional entropy (Auster 1974, 1983), e.g., a CEO running an organization, a government collecting taxes from organizations, or an individual taking a position in a company after studying at university. Low institutional entropy means ordered interactions which produce outcomes that are beneficial. Institutional entropy is a component of what has been referred to as social entropy (Bailey 1990, 2006) and social capital (Putnam 2000). In the polycentric organization of social systems, social capital can be built by bonding and bridging, and similarly, institutional innovations can be the result of vertical or horizontal value creation.

Innovations from horizontal value creation result from a combination of actions (or materials) within a given biophysical or social environment. Horizontal value creation in social systems (bonding) happens by improving social and exchange relationships, or enforcing trust and solidarity. Assembling parts to build tools and machines or recycling waste for new uses are examples of horizontal value creation in physical systems. The marginalized benefit from horizontal value creation by being integrated into and benefiting from community activities and local networks and by making use of simple technological solutions. Rotating savings and credit associations in Indonesia (Varadharajan undated) are an example. Creating value through strong ties and identities within the community is an important social safety net, but it can also be a disincentive to break out of the bonds and create value vertically.

Vertical value creation in polycentric systems happens by connecting to actors and networks outside one's own networks or by making use of the rules and policies at a higher level of decision-making. Linking to knowledge and social systems beyond the local level opens opportunities for value creation by having access to external assets and information and by making rules instead of only obeying them. Gupta et al. (2003) provide the example of the Gujarat Grassroots Innovation Augmentation Network (GIAN). GIAN adds value to local innovations by facilitating the shift from innovators to entrepreneurs, access to risk capital, and technological knowhow or design input which transforms the innovation into a commercial product. GIAN also files patents on behalf of the innovators or provides support in building business networks. 
Another example of successful innovation which specifically takes vertical value creation into consideration is the spread of the shallow tubewells for (boro) rice irrigation during the dry season in Bangladesh in the 1980s. The expansion of boro rice production from $10 \%$ in the 1960 s to $60 \%$ of the total rice production by 2008 was triggered by a change in policy which liberalized the procurement and marketing of irrigation equipment in the 1980s. The availability of lower cost machines from China and the elimination of import duties and standardization requirements led to the rapid spread of this technology and an increase in productivity (Hossain 2009).

Vertical and horizontal value creation reduces institutional entropy and serves the purpose of reducing transaction costs (Iskandar and Gatzweiler 2014). Being able to produce, exchange, transact and communicate more efficiently can be achieved by changing the set of rules which structure various types of exchange and interactions. Very often, this has been referred to as "enabling institutional environment" (Joshi and Moore 2000). North (1990, p. 125) lists three types of institutional innovations which have led to increasing economic performance and "the rise of the Western World". They relate to lowering the costs of mobility, capital and information, and spreading the costs of risk in economic exchange relationships.

Horizontal and vertical value creation are not always equally important. Depending on the situation of the marginalized, it may be more important to create strong networks and innovate horizontally through bonding, especially if transcending accustomed behaviors is a threat to survival and social integrity. In those cases, bonding is good for adapting, getting along and building survival networks. In other situations, vertical value creation is an opportunity for getting ahead, connecting to actors at different locations of the value chain, making decisions on rights which secure the benefits from innovation and building mobility networks (Briggs 1989; Briggs et al. 2010; Dominguez and Watkins 2003).

Social and physical technology (Beinhocker 2006, p. 241) ${ }^{4}$ mutually influence each other and co-evolve (van de Ven and Garud 1994; Lewin et al. 1999). The use and diffusion of physical technology very often depends on an enabling institutional environment. Institutions not only provide freedoms and incentives to come up with new ideas and innovate, but also enable diffusion and make use of technological innovations once they are available. Using a new technology will not be considered as long as the costs, risks and modes of use and maintenance are not institutionalized. In order to create benefits from the use of new technology, it might be necessary to change policies or create new organizations, like machine rings, and define property rights related to the use of the technology and the outcomes from said use. Physical technologies may also be a trigger and driver

\footnotetext{
${ }^{4}$ Social technology is referred to by Beinhocker (2006, pp. 242, 261) as, "The rule of law, the existence of property rights, well-organized banking system, economic transparency, lack of corruption and other social and institutional factors." Physical technology are the tools, techniques and machines, and the transmission of the knowledge as to how to produce and make use of them.
} 
for institutional change, as opposed to situations in which a general favorable institutional environment for enabling the use and diffusion of a technology must be achieved first. The use of mobile phones, e.g., has created new forms of social relationships and rules of how to communicate, interact and behave in those social networks (Srivastava 2005; Huberman et al. 2008).

In multi-level polycentric orders, value can be created at horizontal and vertical levels. Value creation at horizontal levels refers to the governance of action situations at one level of decision-making. For example, farmers can cooperate and help each other during the harvest season, or achieve improved productivity resulting from the use of technologies, like improved seeds or fertilizers. Such innovations are the result of doing things differently within existing institutional arrangements. They are adapted to and fitted into status quo social structures without fundamentally changing them. Vertical value creation happens when associations, organizations, networks or cooperatives are established which are specifically designed to change previous cost/benefit streams and interaction patterns. Additional value is created by linking to higher levels of organization, e.g., by improving access to rights and resources and inclusion at higher decisionmaking levels.

Institutional innovation is a continuous process of incremental changes. "Incremental change comes from the perceptions of the entrepreneurs in political and economic organizations that they could do better by altering the existing institutional framework at some margin." (North 1990, p. 6), or it is a response to failure, crisis and constraints, presuming information flows and feedback. North further elaborates (1990, p. 108) that, "The success stories of economic history describe the institutional innovations that have lowered the costs of transacting and permitted capturing more of the gains from trade ...". The existence of transaction and interaction costs and a situation of incomplete information, together with the desire to increase gains from interacting, is therefore a necessary precondition for innovation.

The condition of perfect fit, i.e., a situation in which transaction costs for existing interaction patterns are at a minimum, where actors have the same information and mental models of how the world around them works, and a situation which is perceived as being too expensive to change behavior (e.g., because of contracts), is also referred to as the lock-in effect (North 1990, p. 7). Such lock-in occurs in a state of equilibrium. In such a state, the economy performs in an endless round of activities - something Schumpeter (Greiner and Hanusch 1994, p. 262) termed the "circular flow" - a situation in which demand and supply correspond, and interest rates and savings are equal to zero. Profits and losses are zero too, assuming that there is also no time preference. Time does not play a role because production and consumption are synchronized. For given prices, all economic agents have their 
economic transactions fulfilled. This Walrasian system ${ }^{5}$ is in a state of unending stasis, in which individual tastes, techniques and resources are fixed and no innovation occurs.

Doner (2010) makes the vulnerability argument which explains institutional innovation as a response to failures, pressures or crises. The vulnerability argument says that institutional innovations occur in vulnerable systems, systems in which political leaders are confronted with popular discontent and external pressures. They are under pressure by the need for maintaining living standards, avoiding public unrest, maintaining national security, the need for foreign exchange and acting within scarce budget constraints (Doner et al. 2005). At the level of the individual smallholder, the continued absence of support from outside and the remote and marginalized situation can lead individuals to become creative and find technological solutions for their locality (Gupta et al. 2003).

Schumpeter's (1934) notion of creative destruction can be regarded as creating value through new institutional arrangements and leaving behind those which have hindered innovation and suppressed entrepreneurial growth and development. The entrepreneur breaks out of the circular flow model in equilibrium and diverts capital to novel uses in order to be creative and make use of market niches. In order to finance innovation, he/she diverts labor (from the circular flow) to novel uses. However, because resources are already optimally allocated in the equilibrium state, this diversion leads to instability of the equilibrium state in industrial capitalism, which explains outbursts of violence and catastrophes in the history of capitalism (Schumpeter 1939, 1942).

From a polycentricity perspective, the institutions of marginalized communities are not well linked to higher level orders of decision-making and value creation in specific action situations. The pathways do not exist through which information can flow and the monitoring of the performance of actions could occur. Segmented sections of rural society interact more among themselves than with political and economic elites, and their rights to participate and self-organize are constrained. The linkages between rural populations and decision-making elites are weak and interactions do not take place within viable organizational units which could build up sufficient pressures for triggering institutional reform. The coherence and functioning of nation-states in Africa (Gatzweiler 2013, p. 4) are insufficient and the positions of political leaders are too secure for building up the pressures needed to trigger substantial institutional reforms, as explained in the vulnerability argument.

Without explicitly mentioning polycentricity, Gupta et al. (2003, p. 981) refer to similar dynamics hindering institutional innovation by transcending constraints at

\footnotetext{
${ }^{5}$ Leon Walras (1834-1910) describes a closed circular system of exchange between producers and consumers, firms and households. Humans, in that model, act with regards to themselves and according to a very particular conception of rationality. Their preferences are exogenous, i.e., independent of social context and the preferences of others. This self-regarding feature of economic agents who are not influenced by others is a central building block of the Walrasian model. Without it, the mathematical proof of the efficiency of competitive equilibrium collapses.
} 
one institutional level of the nested hierarchy: "A lot of people have learnt to adapt and adjust to a constraint rather than transcend it. In the case of women based technological problems, this constraint has been a consequence of cultural institutions, which prevented them from acquiring blacksmithy or carpentry tools. Women are very creative in coping with the constraints...."

\section{Conclusions}

Improving the wellbeing of marginalized smallholders means changing their position in polycentric systems to where they have more influence on deciding what they are and what they do. This can be achieved through technological and institutional innovations which emerge from social systems or are introduced to them from outside. Pathways for improving the wellbeing of marginalized smallholders can be found by making use of the enabling functions of institutions and creating value horizontally and vertically.

When connectedness to higher level decision-making is low and the marginalized have little control over the institutions which inhibit them from unfolding their potential, and when social system resilience is sufficiently high to absorb risks from experimentation, innovation will occur, leading to more favorable positions at multiple scales in polycentric systems.

Although appropriate technology innovations need to fit into local social and ecological context in order to be adopted, the process of institutional and technological innovation is triggered by situations of misfit creating costs carried by the economically and socially marginalized. If those costs become too high, decisions will be made to change the status quo and innovation occurs. The trigger for changing institutions will occur when the calculus for institutional innovation is positive, which means when expected benefits from an old set of rules are less than the anticipated benefits from a new set of rules plus all the costs involved in the process of changing the rules.

Technological innovations need to be accompanied by institutional changes if progress towards productivity growth is to be sustainable. Technological innovations often improve efficiency (horizontal value creation), e.g., by reducing labor costs, but they do not always enable marginalized smallholders to create value vertically, e.g., by improving access to rights, services or higher decision-making levels. A sole focus on technology innovations in agriculture can therefore improve agricultural productivity growth but make little progress towards sustainable intensification. Donors, investors and development organizations supporting technological innovations in agriculture therefore need to better understand how technological and institutional innovations change the marginal position of poor smallholders in polycentric systems.

In order to facilitate escape from marginality, a broader concept of value creation in polycentric systems is required that reflects the multiple dimensions in 
which rural smallholders are currently marginalized but also shows diverse pathways down which they could progress.

Open Access This chapter is distributed under the terms of the Creative Commons AttributionNoncommercial 2.5 License (http://creativecommons.org/licenses/by-nc/2.5/) which permits any noncommercial use, distribution, and reproduction in any medium, provided the original author(s) and source are credited.

The images or other third party material in this chapter are included in the work's Creative Commons license, unless indicated otherwise in the credit line; if such material is not included in the work's Creative Commons license and the respective action is not permitted by statutory regulation, users will need to obtain permission from the license holder to duplicate, adapt or reproduce the material.

\section{References}

Acemoglu D, Robinson J (2008) The role of Institutions in growth and development. Working paper No 10. Commission on Growth and Development, The World Bank, Washington, DC

Acemoglu D, Robinson J (2012) Why nations fail, the origins of power, prosperity, and poverty. Crown Business, New York

Aligica P (2014) Institutional diversity and political economy. The ostroms and beyond. Oxford University Press, New York

Aligica P, Tarko V (2012) Polycentricity: from Polanyi to Ostrom, and beyond. Governance 25(2):237-262

Amabile T, Hadley CN, Kramer SJ (2002) Creativity under the gun. Special issue on the innovative enterprise: turning ideas into profits. Harv Bus Rev 80(8):52-61

Amable B (2000) International specialisation and growth. Struct Chang Econ Dyn 11(4):413-431

Aoki M (2001) Toward a comparative institutional analysis. MIT Press, Cambridge, MA

Arnold RA (1980) Hayek and institutional evolution. J Libert Stud 4(4):341-352

Auster RD (1974) The GPITPC and institutional entropy. Public Choice 19(1):77-83

Auster RD (1983) Institutional entropy, again. Public Choice 40(2):211-216

Axelrod R, Cohen MD (1999) Harnessing complexity. Free Press, New York

Bailey KD (1990) Social entropy theory. State University of New York Press, New York

Bailey KD (2006) Living systems theory and social entropy theory. Syst Res Behav Sci 23(3):291-300

Beinhocker E (2006) The origin of wealth. Evolution, complexity and the radical remaking of economics. Harvard Business School Press, Boston

Bledow R (2009) Managing innovation successfully: the value of contextual fit. Dissertation, Justus-Liebig University, Gießen

Briggs XS (1989) Brown kids in white suburbs: housing mobility and the multiple faces of social capital. House Policy Debate 9(1):177-221

Briggs XS, Popkin SJ, Goering J (2010) Moving to opportunity. The story of an american experiment to fight ghetto poverty. Oxford University Press, New York

Carpenter SR, Brock WA (2008) Adaptive capacity and traps. E\&S 13(2):40

Dominguez S, Watkins C (2003) Creating networks for survival and mobility: social capital among African-American and Latin-American low-income mothers. Soc Probl 50(1):111-135

Doner RF (2010) Explaining institutional innovation. Case studies from Latin America and East Asia. Social Science Research Council, New York

Doner RF, Ritchie BK, Slater D (2005) Systemic vulnerability and the origins of developmental states: Northeast and Southeast Asia in comparative perspective. IO 59(2):327-361 
Farrel H, Shalizi C (undated) Evolutionary theory and the dynamics of institutional change. http:// iis-db.stanford.edu/evnts/6595/Farrell-Shalizi_4.3.pdf. Accessed 21 Feb 2014

Folke C, Pritchard L, Berkes F, Colding J, Svedin U (2007) The problem of fit between ecosystems and institutions: ten years later. Ecol Soc 12(1):30. http://www.ecologyandsociety.org/vol12/ iss $1 /$ art30/. Accessed 10 June 2015

Gagliardi F (2013) A bibliometric analysis of the literature on institutional complementarities. Paper presented at the 2nd GROE Meeting, Hitchin, 20-22 Sept 2013. [online] http://www. uhbs-groe.org/user/image/gagliardi.pdf

Gatzweiler FW (2013) Institutional and livelihood changes in East African forest landscapes: decentralization and institutional change for sustainable forest management in Uganda, Kenya, Tanzania and Ethiopia. Peter Lang GmbH, Internationaler Verlag der Wissenschaften, Frankfurt

Gatzweiler FW (2014) Value, institutional complementarity and variety in coupled socioecological systems. Ecosyst Serv 10:137-143

Gatzweiler FW, Hagedorn K (2013) Biodiversity and cultural ecosystem services. In: Levin SA (ed) Encyclopedia of biodiversity, vol 1, 2nd edn. Academic Press, Waltham, pp 332-340

Greiner A, Hanusch H (1994) Schumpeter's circular flow, learning by doing and cyclical growth. J Evol Econ 4(3):261-271. doi:10.1007/BF01236372

Gunkel J (2010) Forms of work satisfaction and creativity (Formen der Arbeitszufriedenheit und Kreativität). Dissertation, Fakultät für Wirtschaftswissenschaften, Technische Universität München, Munich

Gupta AK, Sinha R, Koradia D, Patel R, Parmar M, Rohit P, Patel H, Patel K, Chand VS, James TJ, Chandan A, Patel M, Prakash TN, Vivekanandan P (2003) Mobilizing grassroots' technological innovations and traditional knowledge, values and institutions: articulating social and ethical capital. Futures 35(9):975-987. doi:10.1016/S0016-3287(03)00053-3

Hagedorn K (2008) Segregating and integrating institutions - a dichotomy for nature related institutional analysis. In: Schäfer C, Rupschus C, Nagel U-J (eds) Enhancing the capacities of agricultural systems and producers, proceedings of the second green week scientific conference. Margraf-Publishers, Weikersheim

Hall PA, Gingerich DW (2004) Varieties of capitalism and institutional complementarities in the macroeconomy: an empirical analysis. Max-Planck-Institut für Gesellschaftsforschung, Köln

Hardin G (1968) The tragedy of the commons. Science 162(3859):1243-1248

Hodgson G (2006) What are institutions? J Econ Iss 40(1):1-25

Hossain M (2009) The impact of shallow tubewells and boro rice on food security in Bangladesh. International Food Policy Research Institute, Washington, DC

Huberman BA, Romero DM, Wu F (2008) Social networks that matter: Twitter under the microscope. http://arxiv.org/pdf/0812.1045v1.pdf. Accessed 24 Apr 2014

Iskandar DD, Gatzweiler FW (2014) An optimization model for technology adoption of marginalized smallholders: theoretical support for matching technological and institutional innovations. ZEF Working paper 136. Center for Development Research, University of Bonn, Bonn

Janssen M, Scheffer M (2004) Overexploitation of renewable resources by ancient societies and the role of Sunk-cost effects. Ecol Soc 9(1):2

Janssen MA, Kohler TA, Scheffer M (2003) Sunk-cost effects and vulnerability to collapse in ancient societies. Curr Anthropol 44(5):722-728. doi:10.1086/379261

Joshi A, Moore M (2000) Enabling environments: do anti-poverty programmes mobilise the poor? J Dev Stud 37(1):25-56. doi:10.1080/713600057

King N, Anderson N, West MA (1991) Organizational innovation in the UK: a case study of perceptions and processes. Work Stress 5(4):331-339. doi:10.1080/02678379108257031

Kiser LL, Ostrom E (1982) The three worlds of action: a metatheoretical synthesis of institutional approaches. In: Ostrom E (ed) Strategies of political inquiry. Sage, Beverly Hills

Lewin AY, Long CP, Carroll TN (1999) The coevolution of new organizational forms. Organ Sci 10(5):535-550. doi:10.1287/orsc.10.5.535 
Lewis MW, Welsh MA, Dehler GE, Green SG (2002) Product development tensions: exploring contrasting styles of project management. Acad Manage J 45(3):546-564. doi:10.2307/ 3069380

North DC (1990) Institutions, institutional change and economic performance. Cambridge University Press, Cambridge

North DC, Wallis JJ, Webb SB, Weingast BR (2007) Limited access orders in the developing world: a new approach to the problems of development, World Bank policy research working paper series. World Bank, Washington, DC

North DC, Wallis JJ, Weingast BR (2009) Violence and social orders. A conceptual framework for interpreting recorded human history. Cambridge University Press, New York

Nussbaum M, Sen A (eds) (1993) The quality of life. Clarendon, Oxford

Nyikahadzoi K, Pali P, Fatunbi LO et al (2012) Stakeholder participation in innovation platform and implications for Integrated Agricultural Research for Development (IAR4D). IJAF 2(3):92-100. doi:10.5923/j.ijaf.20120203.03

Ostrom V (1972) Polycentricity. Originally prepared for delivery at the 1972 annual meeting of the American political science association, Washington, DC, Hilton Hotel, 5-9 Sept 1972. Revision published in: McGinnis (eds) Polycentricity and local public economies: readings from the workshop in political theory and policy analysis (1999), pp 119

Ostrom V (1983) Freedon and organization. Workshop in political theory and policy analysis working paper W83-16. Bloomington

Ostrom V (1999a) Polycentricity (1). In: McGinnis M (ed) Polycentricity and local public economies. Readings from the workshop in political theory and policy analysis. University of Michigan Press, Ann Arbor, pp 52-74

Ostrom V (1999b) Polycentricity (2). In: McGinnis M (ed) Polycentricity and local public economies. Readings from the workshop in political theory and policy analysis. University of Michigan Press, Ann Arbor, pp 119-138

Ostrom E (2005) Understanding institutional diversity. Princeton University Press, New Jersey

Ostrom E (2010) Polycentric systems for coping with collective action and global environmental change. Glob Environ Chang 20(4):550-557. doi:10.1016/j.gloenvcha.2010.07.004

Ostrom V, Tiebout CM, Warren R (1961) The organization of government in metropolitan areas: a theoretical inquiry. Am Polit Sci Rev 55(4):831. doi:10.2307/1952530

Ostrom E, Gardner R, Walker J (1994) Rules, games, and common-pool resources. The University of Michigan Press, Ann Arbor

Pakandam B (2009) Why Easter Island Collapsed: an answer for an enduring question. Working papers No 117/09. London School of Economics, London

Putnam RD (2000) Bowling alone, the collapse and revival of American community. Simon and Schuster, New York

Richerson PJ, Boyd R (2001) Institutional evolution in the holocene: the rise of complex societies. In: Runciman G (ed) The origin of human social institutions. Proceedings of the British Academy 110, Oxford University Press, Oxford, pp 197-204

Rizzello S (1999) The economics of the mind. Elgar, Cheltenham

Schumpeter JA (1934) The theory of economic development. Harvard University Press, Cambridge

Schumpeter J (1939) Business cycles: a theoretical, historical, and statistical analysis of the capitalist process. McGraw-Hill, London

Schumpeter JA (1942) Capitalism, socialism and democracy, Harper, 1975 [orig. pub. 1942], New York

Srivastava L (2005) Mobile phones and the evolution of social behaviour. Behav Inform Technol 24(2):111-129. doi:10.1080/01449290512331321910

Van de Ven A, Garud R (1994) The coevolution of technical and institutional events in the development of an innovation. In: Baum JAC (ed) Evolutionary dynamics of organizations. Oxford University Press, Oxford, pp 425-443 
Van den Bergh J, Stagl S (2003) Coevolution of economic behaviour and institutions: towards a theory of institutional change. J Evol Econ 13(3):289-317. doi:10.1007/s00191-003-0158-8

Varadharajan S (undated) Explaining participation in Rotating Savings and Credit Associations (RoSCAs): Evidence from Indonesia, http://www.microfinancegateway.org/gm/document-1.9. 26314/23451_file_Arisan_May.pdf. Accessed 28 Apr 2014

Vatn J (2012) Can we understand complex systems in terms of risk analysis? Proc Inst Mech Eng Part O J Risk Reliab 226(3):346-358

von Braun J, Gatzweiler FW (2014) Marginality, addressing the nexus of poverty, exclusion and ecology. Springer, Dordrecht/Heidelberg/New York/London

Wexler BE (2008) Brain and culture: neurobiology, ideology, and social change. MIT Press, Cambridge, MA/London

Young OR (2002) The institutional dimensions of environmental change: fit, interplay, and scale/ Oran R. Young. Global environmental accord. MIT Press, Cambridge

Young OR, King LA, Schroeder H (2008) Institutions and environmental change: principal findings, applications, and research frontiers. MIT Press, Cambridge 